\title{
A new giant velvet worm from Costa Rica suggests absence of the genus Peripatus (Onychophora: Peripatidae) in Central America
}

\author{
José Pablo Barquero-González ${ }^{1}$, Steven Sánchez-Vargas ${ }^{1} \&$ Bernal Morera-Brenes ${ }^{1}$ \\ 1. Escuela de Ciencias Biológicas, Universidad Nacional, Laboratorio de Sistemática, Genética y Evolución (LabSGE), \\ Heredia, Costa Rica; jopbgon@gmail.com, stevensagrav23@gmail.com, bernal.morera@gmail.com
}

\author{
Received 15-VI-2019. Corrected 22-IX-2019. Accepted 31-I-2020.
}

\begin{abstract}
Introduction: Neotropical onychophoran taxonomy and diversity has been poorly investigated. Recent studies have discovered problems in species classification: they have questioned the accepted genera and the actual number of species. This is true in Costa Rica, where several unidentified species have been reported. Objective: The objective of this investigation was to evaluate the occurrence of the accepted genera in this country, and to describe a new genus and species from Central America. Methods: In 2017, we collected one onychophoran in the Keköldi Indigenous Reserve in Talamanca, Limón, Costa Rica. The specimen gave birth to several offspring. Therefore, seven organisms were analyzed. Light microscopy was used to observe the gross morphology in all samples. The detailed morphology was studied in the biggest specimen with scanning electron microscopy; after that, we performed a phylogenetic analysis with the corresponding sequence of COI. Results: According to our results, a new genus and species of giant onychophoran was found. The genus was identified by its giant size, apical piece of seven scale ranks, large conical primary papillae, dorso-median furrow flanked by two-three accessory papillae, the absence of hyaline organs and a marked sexual dimorphism with respect to the number of legs. The new species presents a particular head pattern, as well as novel structures like cephalic papillae, accessory papillae with rudimentary apical pieces, and a lack of antennal chemoreceptors. Phylogenetic analysis rendered our genus as monophyletic and includes Peripatus solorzanoi, which is grouped within the Central American clade. As our species is clustered inside the Costa Rica-Panamanian group, it is not related to the Caribbean Island nor Guyanan Shield samples, home of Epiperipatus and Peripatus respectively. Therefore, we suggest that those genera do not occur in Central America, and a new genus exists: Mongeperipatus, gen. nov. Conclusion: We concluded that Costa Rica is home to a diversity of undescribed onychophorans that requires specific studies to help clarify the taxonomy and evolutionary relationships of the group to justify their protection.
\end{abstract}

Key words: onychophoran speciation, Costa Rican biodiversity, endemism, saproxilic taxa, phylogenetics.

Barquero-González, J. P., Sánchez-Vargas, S., \& Morera-Brenes B. (2020). A new giant velvet worm from Costa Rica suggests absence of the genus Peripatus (Onychophora: Peripatidae) in Central America. Revista de Biología Tropical, 68(1), 300-320.

Onychophorans are terrestrial invertebrates that inhabit moist habitats (Picado, 1911; Carvalho, 1941; Monge-Nájera, 1995; Zitani et al., 2018). Their peculiar biology (Podsiadlowski, Braband, \& Mayer, 2008; Sampaio-Costa, Chagas-Junior, \& Baptista, 2009; Braband, Podsiadlowski, Cameron, Daniels, \& Mayer, 2010a; Braband, Cameron, Podsiadlowski, Daniels, \&
Mayer, 2010b; Brito, Pereira, Ferreira, Vasconcellos, \& Almeida, 2010; Rota-Stabelli et al., 2010; Lacorte, Oliveira, \& Fonseca, 2011; Chagas-Júnior, \& Sampaio-Costa, 2014; MongeNájera, \& Morera-Brenes, 2015) includes high endemism rates (Oliveira, Wieloch, \& Mayer, 2010; Cunha et al., 2017), the existence of social behavior (Reinhard, \& Rowell, 2005; 
Barquero-González, Vega-Hidalgo, \& MongeNájera, 2019), and the capacity of expelling an adhesive net (Bouvier, 1905; Haritos et al., 2010; Concha et al., 2015; Corrales-Ureña et al., 2017; Baer, Hänsch, Mayer, Harrington, $\&$ Schmidt, 2018). They have been considered living fossils (Garwood et al., 2016). The phylum has two families: Peripatopsidae and Peripatidae (Brinck, 1957; Ruhberg, 1985; Reid, 1996; Mayer, 2007; Allwood et al., 2010; Braband et al., 2010a). Within the latter, neotropical species have been classified as Neopatida (sensu Oliveira et al., 2016). Costa Rican onychophorans have been placed within this group. Even though Costa Rican onychophorans have been studied in the last few years (Morera-Brenes, Monge-Nájera, \& Sáenz, 1988; Monge-Nájera, Barrientos, \& Aguilar, 1993; Monge-Nájera, 1995, Mora, Herrera, \& León, 1995; Monge-Nájera, 1996; MoreraBrenes, \& Monge-Nájera, 2010; Oliveira et al., 2012a; Monge-Nájera, \& Morera-Brenes, 2015; Barquero-González, Acosta-Chaves, Sotela, Villalobos-Brenes, \& Morera-Brenes, 2016a; Barquero-González, Alvarado Cabrera, Valle-Cubero, Monge-Nájera, \& Morera-Brenes, 2016b; Monge-Nájera, 2017; BarqueroGonzález, Morera-Brenes, \& Monge-Nájera, 2018; Barquero-González et al, 2019), their taxonomy remains deficient.

For instance, Peripatidae lacks proper taxonomic characters that could be used to identify them. Therefore, progress in morphology has been slow (Read, 1988a, 1988b; Oliveira et al., 2012a; Sampaio-Costa, Amazonas-Chagas \& Pinto-da-Rocha, 2018). Bouvier (1905) recognized two groups of neotropical species: the Andean clade (with four or more foot papillae, and the nephridial tubercle inserted in the third spinous pad) comprised by the genus Oroperipatus (Cockerell, 1908), and the Caribbean clade (with three foot papillae, and the nephridial tubercle below the third spinous pad). To this day, it remains as the only justified evolutionary division. Other characteristics used to identify genera - including body size, number and shape of teeth, coloration, internal structures, the number of pairs of legs (Sedwick, 1888;
Lavallard, \& Campiglia, 1975; Read, 1985) and of spinous pads - can overlap amongst genera (Read, 1985, 1988a; Oliveira et al., 2012a) or vary within a single species (Bouvier, 1899; Marcus \& Marcus, 1955; Read, 1988a; Oliveira et al., 2010).

Thereby, morphological restrictions are an obstacle to elucidate relationships. On the other hand, while Scanning Electron Microscopy (SEM) permitted a detailed revision of some neopatids (Read, 1988a, 1988b; Oliveira et al., 2012a, 2013, 2014), it has not clarified genera distinction. Dorsal integument - once regarded as highly informative for the group's systematics (Bouvier, 1905; Peck, 1975; Read, 1988a; Sampaio-Costa et al., 2018) - has been questioned (Oliveira et al., 2010) given the supposed fixation artifacts in for example $\mathrm{Mac}$ roperipatus (Clark, 1913). Other authors who proposed unexplored characteristics (Oliveira et al., 2012a) to identify species of Peripatopsidae and Peripatidae (Oliveira et al., 2012a, 2013, 2016; Oliveira, \& Mayer, 2017; Oliveira, Ruhberg, Rowell, \& Mayer, 2018), were successful in this regard and managed to show a higher morphological diversity in the phylum. However, its value at the genera level has still to be proven further. Additionally, some of those characteristics - like interpedal structures, pre-ventral and ventral organs - depend on the contraction of preserved specimens. Moreover, the discovery of cryptic species in both families (Briscoe, \& Tait, 1995; Trewick, 1998, 1999, 2000; Ruhberg, \& Hamer, 2005; Daniels, Picker, Cowlin, \& Hamer, 2009; Daniels, \& Ruhberg, 2010; Oliveira et al., 2010; Daniels, 2011; Oliveira, Lacorte, Fonseca, Wieloch, \& Mayer, 2011; Daniels, McDonald, \& Picker, 2013; Ruhberg, \& Daniels, 2013; Myburgh, \& Daniels, 2015; Daniels, Dambire, Klaus, \& Sharma, 2016; Cunha et al., 2017; Sato, Buckman-Young, Harvey, \& Giribet, 2018) has complicated taxonomic distinctions.

Currently, it is still impossible to identify most genera. Read (1988a, 1988b) distinguished Epiperipatus (Clark, 1913) from Peripatus (Guilding, 1826), based on primary papillae apical piece's scale ranks. He split 
species into three groups: one with more than three scale ranks, the second with three scale ranks, and the last with less than three scale ranks. With this classification, Oroperipatus and Peripatus were classified within the first group; Epiperipatus and most Macroperipatus fell in the second; while M. torquatus and Plicatoperipatus jamaicensis (Peck, 1975) occupied the last group. Since then, there has not been a single revision of the genus Peripatus. When solely considering this distinction, some species classified as Peripatus are grouped into Epiperipatus and vice versa. In fact, SampaioCosta and collaborators (2018) described several Epiperipatus species with a large number of scale ranks on their apical piece, a supposed exclusive character of Peripatus. Simultaneously, Giribet and collaborators (2018) showed that different species tend to be grouped by geographic location instead of genera, weakening genera validity and leaving the taxonomy of new species uncertain.

In Costa Rica, the occurrence of unidentified species (Barquero-González et al., 2016a, 2016b), has served as a motivation to explore the biodiversity of the taxa and to face the taxonomic issues. Therefore, based on locations provided by previous studies, we collected and described an onychophoran from the Caribbean side the country, which cannot be classified within the accepted genera. Considering our findings, we suggest a new genus of giant onychophorans endemic to Costa Rica (Mongeperipatus) and argue about the absence of a true representative of the genus Peripatus.

\section{MATERIALS AND METHODS}

Study site: From March to May 2017, we surveyed various locations on the districts of Talamanca (mainly in the Keköldi Indigenous Reserve), Limón, Costa Rica, for onychophorans, and managed to find a sample. The specimen was collected using the Sistema Nacional de Áreas de Conservación (SINAC) licenses (SINAC-SE-CUSBSE-PI-R-133-2016 and SINAC-SE-CUSBSE-PI-R-015-2017) and its geographic location was registered (Fig. 1).
This individual subsequently gave birth to several offspring during its time in captivity.

DNA sequences: A sequence of cytochrome oxidase I (COI) from the studied specimen was generated and donated by colleagues from the Universidad de Costa Rica on October 2017. Sequence data of other Neotropical species (Morera-Brenes, \& Monge-Nájera, 2010; Oliveira et al., 2012a; Murienne, Daniels, Buckley, Mayer, \& Giribet, 2014; Giribet et al., 2018) were acquired from The National Center for Biotechnology Information. To increase phylogenetic resolution, we avoided outgroups like Eoperipatus and Mesoperipatus given the long branches between them and neopatids (Giribet et al., 2018). Our final matrix had 47 species sequences for COI, 47 species for $12 \mathrm{~S}, 41$ species for $16 \mathrm{~S}$ and 37 species for $18 \mathrm{~S}$ (Table 1). Alignments were made with MAFFT web server (Katoh, Kuma, Toh, \& Miyata, 2005; Kuraku, Zmasek, Nishimura, \& Katoh, 2013), G-INS-i strategy was used for COI, $12 \mathrm{~S}$ and 16S genes; and E-INS-i strategy was used for $18 \mathrm{~S}$ gene (Sato et al., 2018). Each gene alignment was trimmed using the Gblocks web server (Castresana, 2000). Additionally, default parameters settings for DNA global alignment with free end gaps were used. Sequences were concatenated with SequenceMatrix 1.8 (Vaidya, Lohman, \& Meier, 2011). Then, we used the Akaike information criterion (Akaike, 1973) to evaluate the best fit substitution model for each gene (Digital Appendix 1) using JModelTest 2.1.10 (Posada, 2008).

Phylogenetic analysis: We conducted a Bayesian inference analyses on CIPRES Science Gateway version 3.3 (Miller, Pfeiffer, \& Schwartz, 2010), with MrBayes 3.2.6 (Ronquist et al., 2012) on XSEDE. Each analysis comprised two independent Markov Monte Carlo Chains (MCMC) runs, with four chains of 10 million generations each, sampling every 1000 generations with default parameters. A burn-in of $50 \%$ was included in the command. A consensus tree was obtained after the analysis as part of our output. Convergence was 


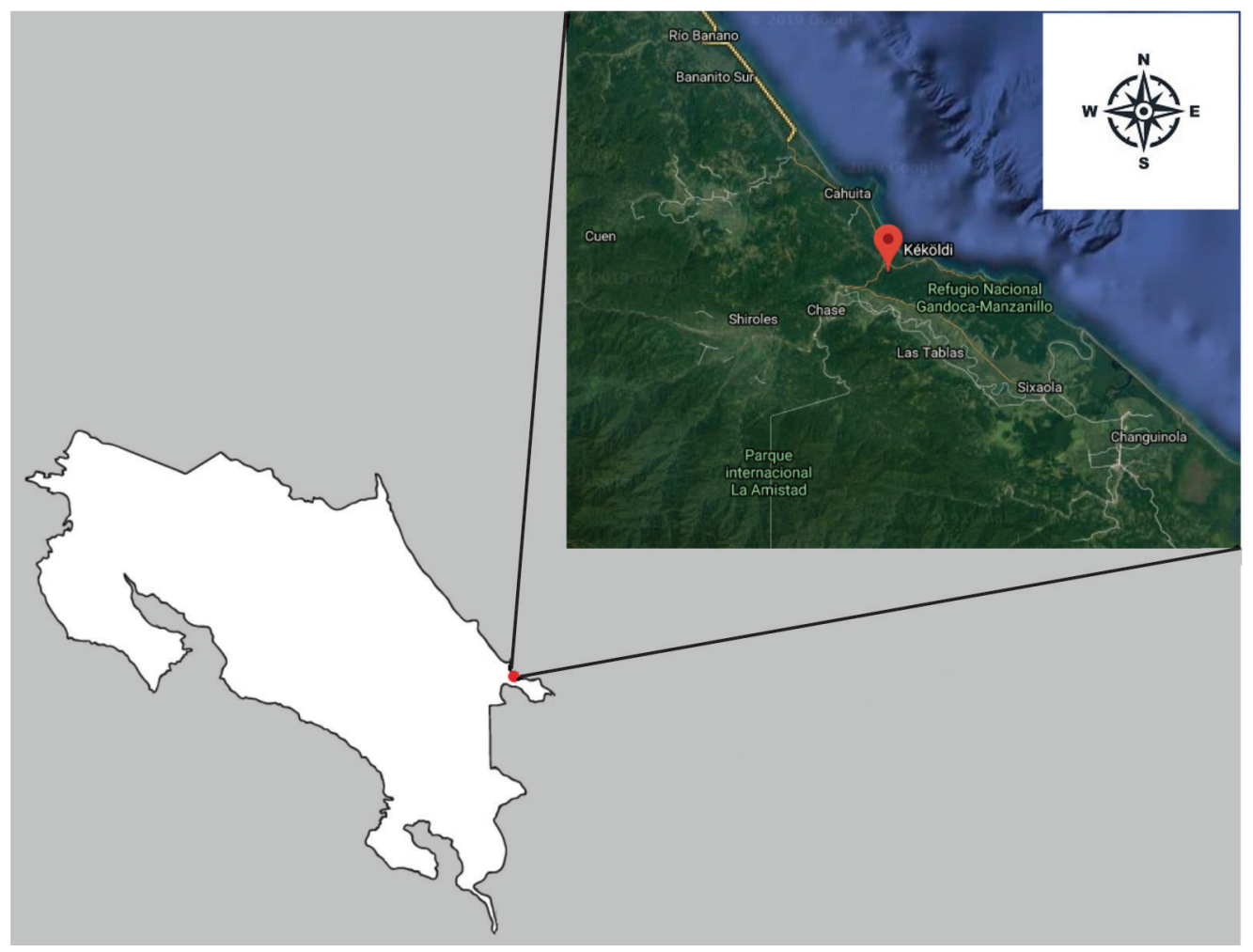

Fig. 1. Map of Costa Rica illustrating the exact location of our species.

TABLE 1

Taxon IDs with GenBank collection accession numbers for studied specimens

\begin{tabular}{lcccccc}
\multicolumn{1}{c}{ Species } & Catalog no. & Region & COI & 12S & 16S & 18S \\
Epiperipatus adenocryptus & ONY-SBL011 & Brazil & HQ236114 & HQ236140 & - & - \\
Epiperipatus adenocryptus & ONY-SBL008 & Brazil & JN564575 & - & - & - \\
Epiperipatus acacioi & ONY-ITA001 - & Brazil & HQ404904 & HQ404922 & MG973517 & MG973554 \\
& MNRJ:0044 & & & & & - \\
Epiperipatus acacioi & Tripuil & Brazil & HQ655588 & HQ404920 & - & MG973561 \\
Epiperipatus cf. edwardsii & MCZ 131427 & French Guiana & MH107336 & MG973702 & MG973468 & MG \\
Epiperipatus edwardsii & GF180312HC003-06 - & French Guiana & HG531958 & HG531961 & HG531962 & MG973542 \\
& MCZ:141306 & & & & & \\
Epiperipatus diadenoproctus & ONY-MDS010 & Brazil & HQ236095 & HQ236121 & - & - \\
Epiperipatus paurognostus & UFMT & Brazil & MH107346 & MG973696 & MG973516 & MG973553 \\
Epiperipatus sp. & MZUSP 0090 & Brazil & MH107338 & MG973653 & MG973479 & MG973550 \\
Epiperipatus sp. & MCZ 131428 & Colombia & MH107352 & MG973706 & MG973525 & MG973590 \\
Epiperipatus sp. & MCZ 131430 & Colombia & MH107354 & MG973708 & MG973527 & MG973592 \\
Epiperipatus sp. & MZUP 0112 & Panama & MH107360 & MG973684 & MG973490 & MG973577 \\
Epiperipatus sp. & MZUP 0111 & Panama & MH107359 & MG973683 & MG973489 & MG973576 \\
Epiperipatus sp. & UNACHI & Panama & MH107365 & MG973685 & MG973491 & MG973578 \\
Epiperipatus vagans & MZUSP 0114 & Panama & MH107350 & MG973665 & MG973484 & MG973547 \\
Epiperipatus vagans & MZUSP 0101 & Panama & MH107349 & MG973663 & MG973482 & MG973544 \\
\hline & & & & & &
\end{tabular}


TABLE 1 (Continued)

\begin{tabular}{|c|c|c|c|c|c|c|}
\hline Species & Catalog no. & Region & COI & $12 \mathrm{~S}$ & $16 \mathrm{~S}$ & $18 \mathrm{~S}$ \\
\hline Epiperipatus vagans & MZUSP 0113 & Panama & MH107348 & MG973664 & MG973483 & MG973545 \\
\hline Epiperipatus vagans & MZUSP 0115 & Panama & MH107347 & MG973666 & MG973485 & MG973546 \\
\hline Macroperipatus valerioi & MCZ 130841 & Costa Rica & MH107341 & MG973681 & MG973496 & MG973558 \\
\hline Macroperipatus valerioi & MCZ 130842 & Costa Rica & MH107342 & MG973682 & MG973497 & MG973569 \\
\hline Macroperipatus torquatus & MCZ 143928 & Trinidad & MH107344 & MG973699 & MG973504 & MG973562 \\
\hline Macroperipatus sp. & DNA104651 & Colombia & KC754644 & - & KC754527 & - \\
\hline Epiperipatus trinidadensis & MCZ 143926 & Trinidad & MH107343 & - & MG973513 & - \\
\hline Oroperipatus eisenii & MCZ 71297 & Mexico & MH107369 & MG973712 & MG973531 & - \\
\hline Oroperipatus sp. & MCZ 43394 & Galapagos & MH107372 & MG973716 & MG973532 & MG973603 \\
\hline Oroperipatus sp. & $\begin{array}{l}\text { MNRJ } 0069 \text { - } \\
\text { MCZ131387 }\end{array}$ & Ecuador & MH107368 & MG973711 & MG973530 & MG973604 \\
\hline Oroperipatus sp. & DVL2011 & Belize & NC015890 & JF800076 & JF800076 & - \\
\hline Peripatus basilensis & MCZ131422 & $\begin{array}{c}\text { Dominican } \\
\text { Republic }\end{array}$ & KC754646 & MG973700 & MG973471 & MG973563 \\
\hline Peripatus juanensis & MCZ 133568 & Puerto Rico & - & MG973693 & MG973500 & MG973565 \\
\hline Peripatus juanensis & MCZ 133570 & Puerto Rico & - & MG973694 & MG973501 & MG973567 \\
\hline Peripatus juanensis & MCZ 133572 & Puerto Rico & - & MG973691 & MG973498 & MG973566 \\
\hline Peripatus sp. & MCZ 131445 & Guyana & MH107374 & MG973701 & MG973528 & - \\
\hline Peripatus solorzanoi (type) & PE11 (red) & Costa Rica & KM095130 & KM095128 & - & - \\
\hline Peripatus solorzanoi & PE12 & Costa Rica & KM095131 & KM095129 & - & - \\
\hline Peripatus solorzanoi & MCZ 130840 & Costa Rica & - & MG973679 & MG973486 & MG973580 \\
\hline Peripatidae sp. & MZUSP 0019 & Brazil & MH107356 & MG973655 & MG973478 & MG973548 \\
\hline Peripatus sp. & MCZ 46445 & Guyana & MH107337 & MG973703 & MG973470 & MG973583 \\
\hline Peripatidae sp. & MCZ32028 & Venezuela & MH107366 & MG973676 & MG973524 & MG973581 \\
\hline Peripatus sp. & MZUSP 0102 & Panama & MH107357 & MG973677 & MG973522 & MG973571 \\
\hline Peripatus sp. & MZUSP 0103 & Panama & MH107358 & MG973678 & MG973523 & MG973572 \\
\hline Peripatidae sp. & MZUSP 0106 & Panama & MH107364 & MG973686 & MG973493 & MG973573 \\
\hline Peripatidae sp. & MZUSP 0108 & Panama & MH107361 & MG973687 & MG973495 & MG973575 \\
\hline Peripatidae sp. & MZUSP 0110 & Panama & MH107363 & MG973688 & MG973494 & MG973579 \\
\hline Epiperipatus biolleyi & NC009082 & Costa Rica & NC009082 & NC009082 & NC009082 & $\begin{array}{l}\text { AF370782 - } \\
\text { AF370783 }\end{array}$ \\
\hline Epiperipatus biolleyi & HM600781 & Costa Rica & HM600781 & HM600781 & HM600781 & MG973570 \\
\hline Principapillatus hitoyensis & MCZ131340 & Costa Rica & MH107340 & MG973680 & MG973488 & MG973555 \\
\hline Principapillatus hitoyensis & DNA103564 & Costa Rica & KC754642 & KC754476 & KC754525 & KC754575 \\
\hline Principapillatus hitoyensis & PH1 - MCZ131339 & Costa Rica & JX568983 & JX568960 & - & MG973556 \\
\hline Principapillatus hitoyensis & PH12 & Costa Rica & JX568994 & JX568971 & - & - \\
\hline Principapillatus hitoyensis & PH13 & Costa Rica & JX568995 & JX568972 & - & - \\
\hline New species (ONI068) & ONI068 & Costa Rica & $* *$ & - & - & - \\
\hline
\end{tabular}

$* *=$ Sequence waiting for code assignation.

checked in Tracer 1.7.0 (Rambaut, Drummond, Xie, Baele, \& Suchard, 2018). Trees were edited and visualized with Figtree v1.4.1.

Morphology: We used the terminology established by Oliveira and collaborators (2010) for the description. Gross morphology was recorded in seven specimens (Digital Appendix 2). One paratype was used for SEM analysis. We compared the autapomorphies of the extant genera of Peripatidae (Peck, 1975; Oliveira et al., 2012a; Oliveira, Read, \& Mayer, 2012b; Oliveira et al., 2013, Sampaio-Costa et al., 2018 ) with our specimens and with $P$. solorzanoi 
(Morera-Brenes, \& Monge-Nájera, 2010) given their similarity in size and morphology in order to assign them to a genus (Table 2).

Scanning Electron Microscopy: Specimens were preserved in $70 \%$ ethanol and $20 \%$ ethanol after distention. Small pieces from the biggest female (paratype) were treated in the following order: they were rehydrated and redistended progressively in 50, 30, 15 and $5 \%$ ethanol and distilled water for 15 min each and, later, in $\mathrm{OsO}_{4}$ for two hours. Then, they were treated in distilled water for $15 \mathrm{~min}$ and tannic acid followed by two hours in $\mathrm{OsO}_{4}$ and two rinses in distilled water (15 min each). After
$15 \mathrm{~min}$ of a $5,15,30,50,70,80,90,95$ and $100 \%$ ethanol series each (the $100 \%$ treatment was repeated three times) and critical point drying, the pieces were gold-coated for 10-15 min (Morera-Brenes \& Monge-Nájera, 1990), and its morphology was observed in a Hitachi S3700 Scanning Electron Microscope.

Deposition of type specimens: Specimens were deposited in the collection of the Museo de Zoología of Universidad de Costa Rica (MZUCR).

Nomenclatural acts: This work and its respective nomenclatural act were registered

TABLE 2

Autapomorphies from each genus compared to the analyzed species

\begin{tabular}{|c|c|c|c|}
\hline Genus & Distinctive character & New species & P. solorzanoi \\
\hline Cerradopatus & $\begin{array}{l}\text { Large female genital pad, covered with modified scales, smaller than } \\
\text { those covering dermal papillae. }\end{array}$ & 0 & 0 \\
\hline Eoperipatus & $\begin{array}{l}\text { Males with a single and medial anal gland opening; four circular pits } \\
\text { on the male gonopore; a single complex formed by the crural tubercles } \\
\text { united by a dermal fold. }\end{array}$ & 0 & 0 \\
\hline Epiperipatus & $\begin{array}{l}\text { Primary papillae base with } 4-18 \text { scale ranks. Apical pieces from } \\
\text { conical-cylindrical to flat. Four complete and rarely remains of a fifth } \\
\text { spinous pad. One-tree pregenital legs with crural papillae (male only). }\end{array}$ & $0 / 1$ & $0 / 1$ \\
\hline Heteroperipatus & One posterior and three anterior distal foot papillae. & 0 & 0 \\
\hline Macroperipatus & $\begin{array}{l}\text { Dermal papillae with quadrangular bases, covered with flat scales; } \\
\text { primary papillae with undeveloped apical pieces, only one collar of } \\
\text { small scales. }\end{array}$ & 0 & 0 \\
\hline Mesoperipatus & $\begin{array}{l}\text { Male anal gland openings in a single medial groove before the anus, } \\
\text { separated by a dermal fold; three spinous pads per leg. }\end{array}$ & 0 & 0 \\
\hline Oroperipatus & Two or more distal foot papillae on anterior and posterior foot region. & 0 & 0 \\
\hline Peripatus & $\begin{array}{l}\text { More than two crural tubercles present in pregenital leg pairs in males; } \\
\text { dorsal primary papillae apical piece larger than basal piece. }\end{array}$ & 0 & 0 \\
\hline Plicatoperipatus & $\begin{array}{l}\text { Each segment with twenty-four dorsal plicae, "apical-most scales of } \\
\text { basal piece thorn-shaped, as high as the apical piece and sticking out" } \\
\text { (Oliveira et al., 2012a) }\end{array}$ & 0 & 0 \\
\hline Principapillatus & $\begin{array}{l}\text { Largest and medium-sized primary papillae arranged in an alternated } \\
\text { pattern; plica with large primary and accessory papillae alternate with } \\
\text { plica with small to medium-sized primary papillae and accessory } \\
\text { papillae }\end{array}$ & $0 / 1$ & $0 / 1$ \\
\hline Speleoperipatus & Eyes are not visible; body pigmentation absent & 0 & 0 \\
\hline Typhloperipatus & Eyes not visible; uterine embryos of almost the same age & 0 & 0 \\
\hline
\end{tabular}

$0=$ absence $; 1=$ presence $; 0 / 1=$ some characters are present. 
in the International Commission of Zoological Nomenclature (ICZN). The ZooBank Life Science Identifiers can be consulted using a web browser. The LSID for this study is: urn:1sid:zoobank.org:pub:0FF9536A-EFC848B8-9457-9D7EF5F7E891

\section{RESULTS}

Phylogenetic analysis: The final alignment of gene sequences consisted of $764 \mathrm{bp}$ for COI, $327 \mathrm{bp}$ for $12 \mathrm{~S}, 353 \mathrm{bp}$ for $16 \mathrm{~S}$ and 1 $788 \mathrm{bp}$ for $18 \mathrm{~S}$ nucleotide positions. We rooted our tree between Bouvier's (1905) "Andean Clade" and the rest of Neotropical Peripatidae ("Caribbean Clade" Bouvier, 1905), as done by Giribet and collaborators (2018). Our analysis achieved convergence (Digital Appendix 3A, B, C, Digital Appendix 4, Digital Appendix 5, Digital Appendix 6) and revealed two clades corresponding to the Andean and Caribbean groups (Bouvier, 1905), as previously reported (Giribet et al., 2018). The first one is formed by the Oroperipatus species from Mexico, Ecuador and Galapagos, while the second included the rest of the samples. Within the latter, South American samples from Brazil, the Guyanan Shield and Dominican Republic formed a group.

Another group contained specimens of Epiperipatus and Macroperipatus from Colombia. The next group had species from Central America, Trinidad and Venezuela. The Panamanian E. vagans was excluded from the cluster formed by most individuals from Costa Rica and Panama. In the latter group our species and P. solorzanoi formed a monophyletic clade (Morera-Brenes \& Monge-Nájera, 2010). This suggests a close evolutionary relationship. P. solorzanoi is comprised of two lineages (Fig. 2): one is composed by the type specimen (Morera-Brenes \& Monge-Nájera, 2010) and other by the one analyzed by Giribet and collaborators (2018). The exceptions to the geographic groups were Peripatus MCZ131445 of Guyana - which is outside the South American clade - and O. eisenii from Mexico - which is related to Oroperipatus from Ecuador and Galapagos.

Morphological characters: Our species and $P$. solorzanoi lacked the autapomorphies of the accepted genera, with two partial exceptions: Epiperipatus and Principapillatus (Table 2). The two taxonomical approaches suggested by Giribet and collaborators (2018) were to include this species within the genus Peripatus or to propose a new genus based on the character combination found. Given these options, we proposed another alternative (see Discussion).

Taxonomy: Since the morphological and phylogenetic analysis showed little to no similarities of this specimen with the ones previously identified, we propose a new genus for the Peripatidae family:

\section{Family PERIPATIDAE}

Bouvier, 1902

Genus Mongeperipatus, gen.nov. BarqueroGonzález, Sánchez-Vargas \& Morera-Brenes; urn:1sid:zoobank.org:pub:0FF9536A-EFC848B8-9457-9D7EF5F7E891

Type species: Mongeperipatus keköldi, gen. et sp. nov. by designation

Diagnosis: Giant size in adults, biggest specimens reach between $18-22 \mathrm{~cm}$ in length; dorsal integument with large conical shaped primary papillae (Fig. 3B, Fig. 4B). Dorsomedian furrow is flanked by two-three accessory papillae (Fig. 5A). Conical apical piece with four to seven scale ranks and a central sensory bristle, thorn-shaped, straight or slightly curved with an ornamented base (Fig. 5B, Fig. 5C). Hyaline organs are absent (Fig. 5D). A marked sexual dimorphism is seen in the number of legs (32-34 pairs in males and 37-41 pairs in females).

Non-Diagnostic: Plica with largest primary papillae alternate with mid-sized primary papillae. Larger primary papillae with 9-18 scale ranks (Fig. 5C). Two posterior and one 


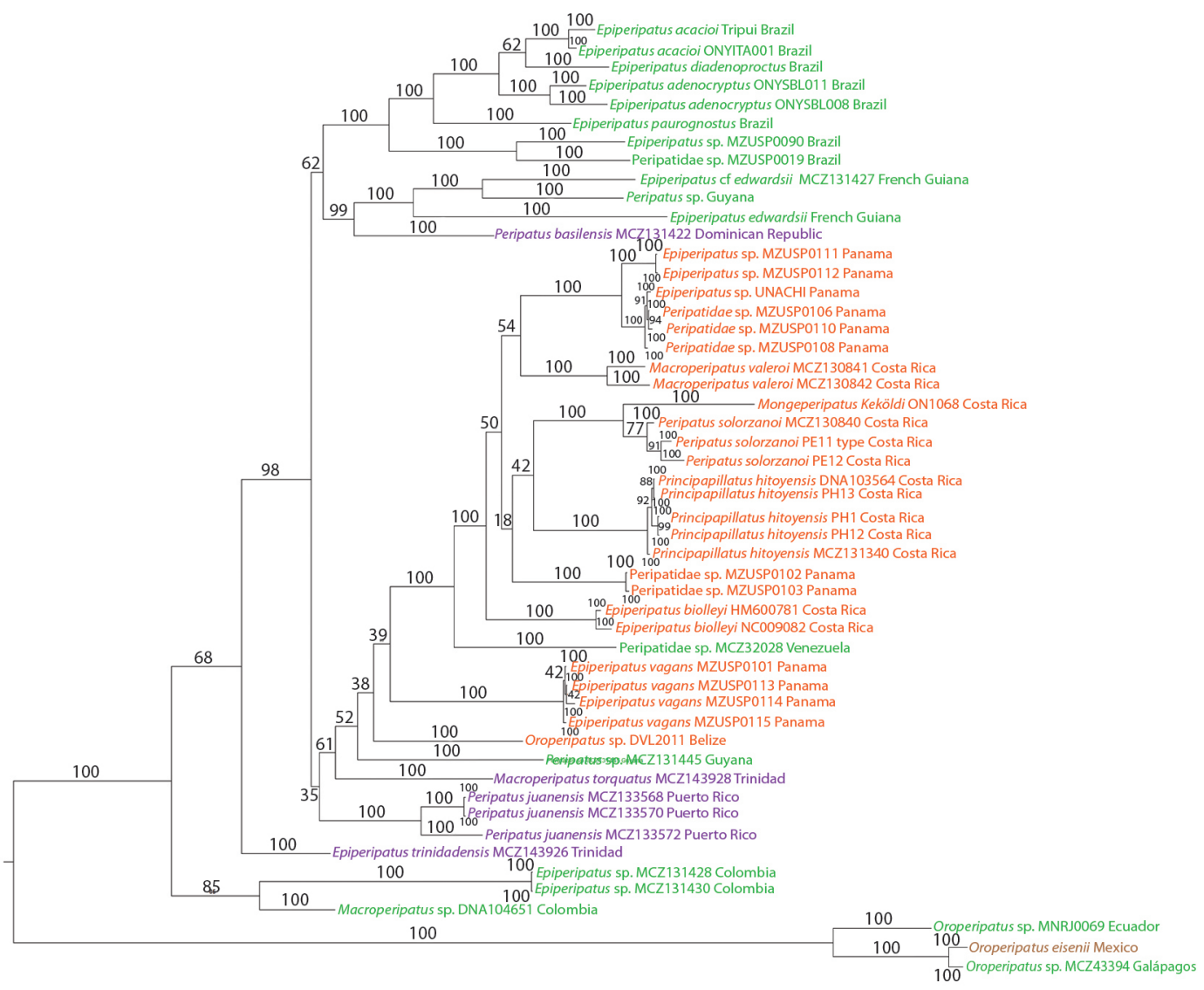

Fig. 2. Bayesian analysis of the dataset. Posterior probability support is given in each node. Distinct geographic regions are represented by different colors: South America (green), Central America (red), Caribbean Islands (purple) and Mexico (brown).

Fig. 2. Análisis bayesiano del set de datos. Los valores de soporte de probabilidad posterior se dan en cada nodo. Las distintas regiones geográficas se representan con colores diferentes: América del Sur (verde), América Central (rojo), Islas Caribeñas (morado) y México (café).

anterior foot papillae (Fig. 5C, Fig. 5D, Fig. 6A) corresponding to the Caribbean clade (Bouvier, 1905). Slightly curved spinous pads on each leg (Fig. 6A, Fig. 6B). Nephridial tubercle in fourth and fifth leg pairs indenting both the third and fourth pad, which is slightly deformed (Fig. 6B).

Distribution: Costa Rica, cantons of Limón, Matina, Siquirres and Talamanca, Limón Province.

Etymology: The genus Mongeperipatus is dedicated to the biologist, photographer and scientific editor Julián Monge Nájera. He started his career studying tropical freshwater turtles and arboreal snakes, and then shifted to snail ecology. Later he specialized on the behavior of Hamadryas butterflies. In the decade of 1990, he moved to the field of behavior, ecology and biogeography of Onychophora, including organisms from the marine Cambrian communities in Southern China. In this field, he has made outstanding contributions.

\section{Species description.}

Mongeperipatus keköldi, sp. nov.

Holotype: One female, in $70 \%$ ethanol, deposited in the Museo de Zoología of the 
Universidad de Costa Rica, San José, Costa Rica (MZUCR 73-01), 9 October 2017, J. Barquero-González col. Paratypes (MZUCR 73-02) - a total of one male and two females.

Type locality: COSTA RICA, Talamanca, Reserva Indígena Keköldi, Tropical Wet Forest in Holdridge (1967) system, 100-200 m.

Diagnosis: Peculiar head pattern: An oval shaped central area with underdeveloped smooth accessory papillae is surrounded on its posterior side by six primary papillae (Fig. 4B, C). Antennal chemoreceptors absent (Fig. 3B). Between antennal bases, it has a well-developed rounded and paired "cephalic papillae" lacking an apical piece (Fig. 4B, Fig. 4C, Fig. 4D). Dorsally, largest and medium primary papillae usually alternate, some accessory papillae have remnants of one-three apical pieces on its sides (Fig. 5A, Fig. 5D). A vestigial fifth spinous pad is present (Fig. 6A). 32-33 pairs of legs in males and 37-39 pairs in females. COI sequence as in the studied specimen.

Measurements: Maximum length of our biggest female (used for SEM studies), deposited as paratype, was $18 \mathrm{~cm}$ alive, including antennae. After being fixed in $70 \%$ ethanol, the size was reduced to $12 \mathrm{~cm}$.

\section{Non-diagnostic features}

Head. 54-66 antennal rings (Fig. 3A, Fig. 3B, Fig. 3D), first two rings of antennal tip with type II sensillum (Fig. 3B). From the third to the $18^{\text {th }}$ antennal ring type I and II, sensillum are present, frequently alternating with narrow rings with type II sensillum (Fig. 3A, Fig. $3 \mathrm{D})$. Ventrally, from the $45^{\text {th }}$ antennal ring to its base, spindle-shaped sensilla appear (Fig. $3 C)$. Dorsally, from the $19^{\text {th }}$ ring to the base, only type I sensillum are found (Fig. 3D). Eyes with a slightly rugged texture are located laterally behind antennal bases (Fig. 4A). Mouth as in other neopatids (Oliveira et al. 2012a), one accessory tooth on the outer jaw, one-two accessory tooth on the inner jaw with 8-11 blunt shaped denticles (Digital Appendix 7A, B).

Dorsal integument. 12 dorsal plicae per segment, seven cross to the ventral side, incomplete or bifurcated dorsal plicae above legs base, and primary papillae rarely with two apical pieces (Fig. 5A). Roundish papillae bases (Fig. 5A, Fig. 5C). Larger primary papillae with nine-twelve scale ranks. Its base is surrounded by a 41-45 scale collar. Medium sized primary papillae with six-eight scale ranks, and its base surrounded by a 37-40 scale collar (Fig. 5C). Primary papillae scales with pointed sharp apex from which three long roots with few to no ramifications emerge (Fig. 5B). Three accessory papillae present between two primary papillae (Fig. 5A).

Ventral integument. Ventral, preventral organs and interpedal structures not observed, given the fixation of ventral integument (Fig. 7C). Type I crater shaped papillae (sensu Oliveira et al., 2012a) with no rudimentary apical piece, with 13-15 scales and a narrow longitudinal central slit (Fig. 7D). Ventral papillae are separated by a longitudinal integument fold with narrow scales and a central stripe of smooth tegument (Fig. 8A). Type II crater shaped papillae like type I, but with a rudimentary central apical piece (Fig. 8B). The crater shaped papillae scales have a similar texture to the primary papillae.

Legs. First spinous pad smaller than the two subsequent ones. Second and third ones similar in size, the fourth narrower and the fifth one is vestigial. Two types of spinous pad bristles: one with thin long roots emerging from the bristle base and extending to a short basal piece, with few ranks of scales (Fig. 7A); another with short roots emerging from the bristle base with numerous scales to a longer basal piece with numerous scales ranks (Fig. 7B). The penultimate pair of legs with three pads, last pair of legs with two pads (Fig. 8C). 

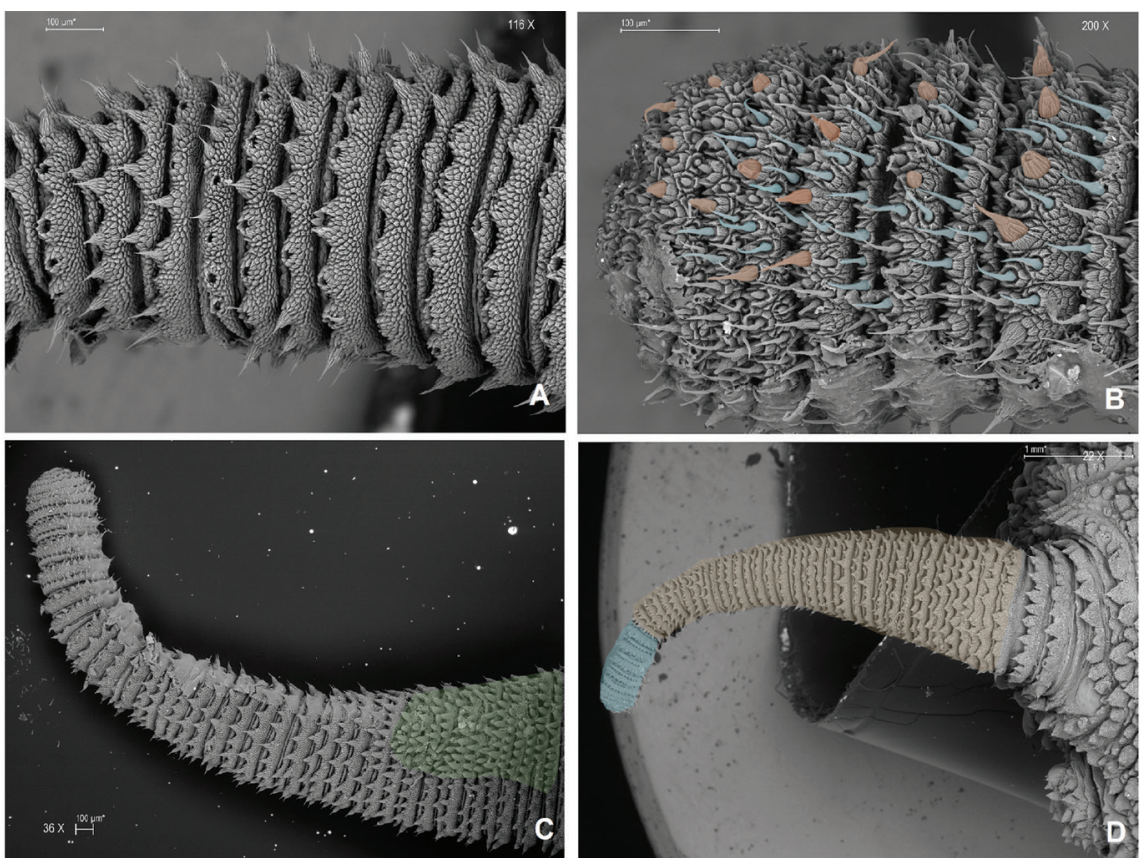

Fig. 3. A. Type I sensillum occur in the mid antennal body; B. Antennal tip with type II (light blue) and type I sensillum (orange), smaller rings with type II sensillum are frequent. C. Ventral antennal view with spindle-shaped sensillum (green) near its base. D. Dorsal view, type II sensillum near antennal tip (light blue), the rest of the antennae have type I sensillum. (Color in digital version).
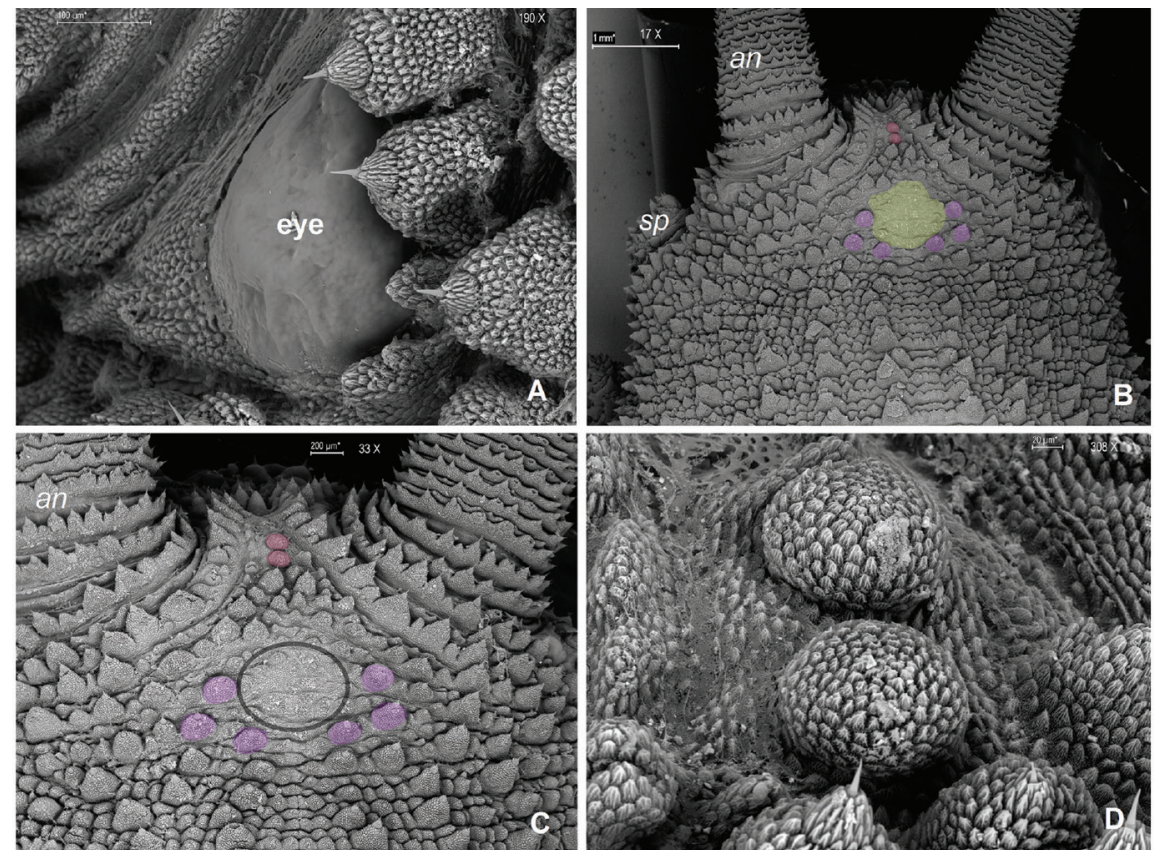

Fig. 4. A. Eye with slightly rugged texture. B. Dorsal head view: low developed accessory papillae with smooth texture (yellow) are surrounded posteriorly by six primary papillae (purple); paired round papillae (pink) appear between antennal bases. C. Detail of head pattern. D. Paired "cephalic papillae" resembling primary papillae lacking an apical piece. Abbreviations as follows: antennae (an); slime papillae (sp). (Color in digital version). 

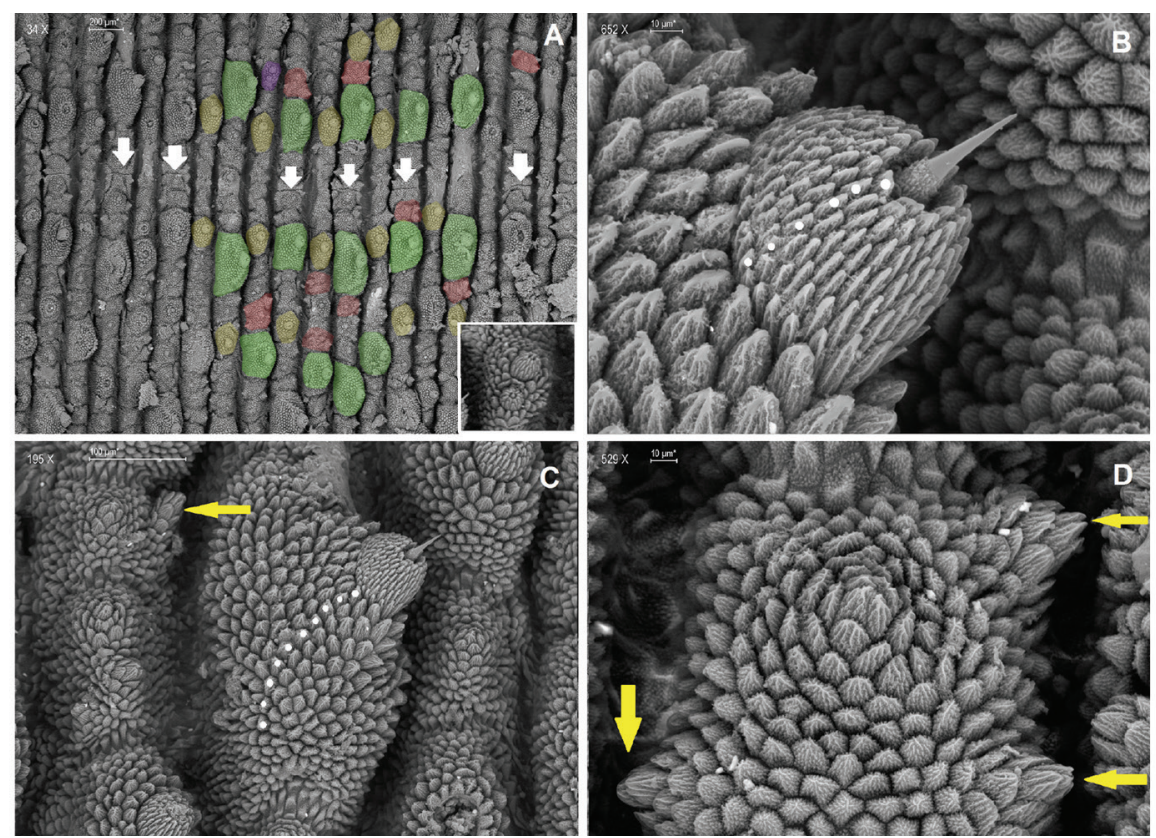

Fig. 5. A. Dorsal integument, plicae with largest primary papillae (green) alternate with plicae with mid-sized primary papillae (yellow), accessory papillae including the new kind (red) are found in groups of three between each primary papillae; primary papillae with two apical pieces (purple) is detailed on the inset, dorsomedian furrow pointed by white arrows; B. Apical piece on primary papillae with five-seven scale ranks; C. Ten scale ranks found on primary papillae; D. Accessory papillae with rudimentary apical pieces are highlighted by yellow arrows. (Color in digital version).
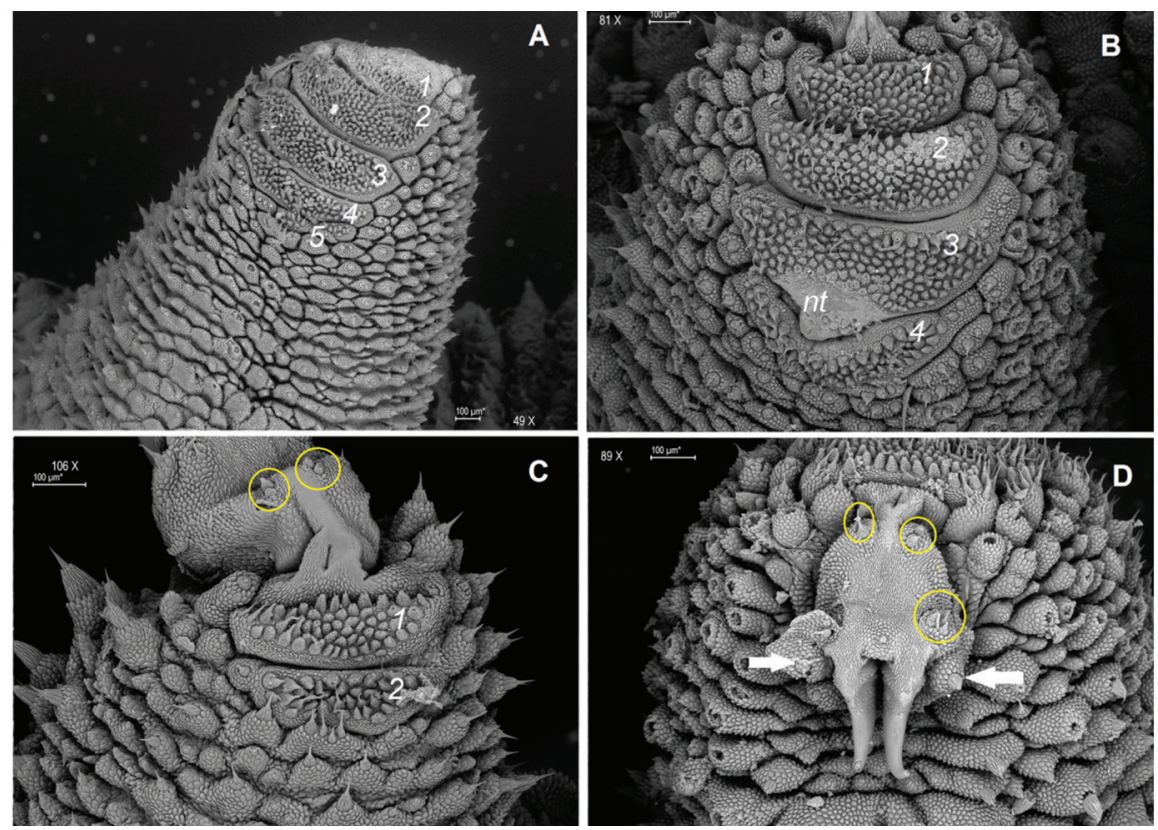

Fig. 6. A. Four complete and the rudiment of a fifth spinous pad are present in most legs; B. Nephridial tubercle indents third and fourth pads; C. Two spinous pads appear in the last pair of legs; D. Two-three bristles occur both on the proximal and distal setiform ridges (yellow circles) of the paw; two posterior (only one is seen given fixation position) and one anterior foot papillae are signaled by white arrows. Abbreviations as follows: nephridial tubercle (nt). (Color in digital version). 

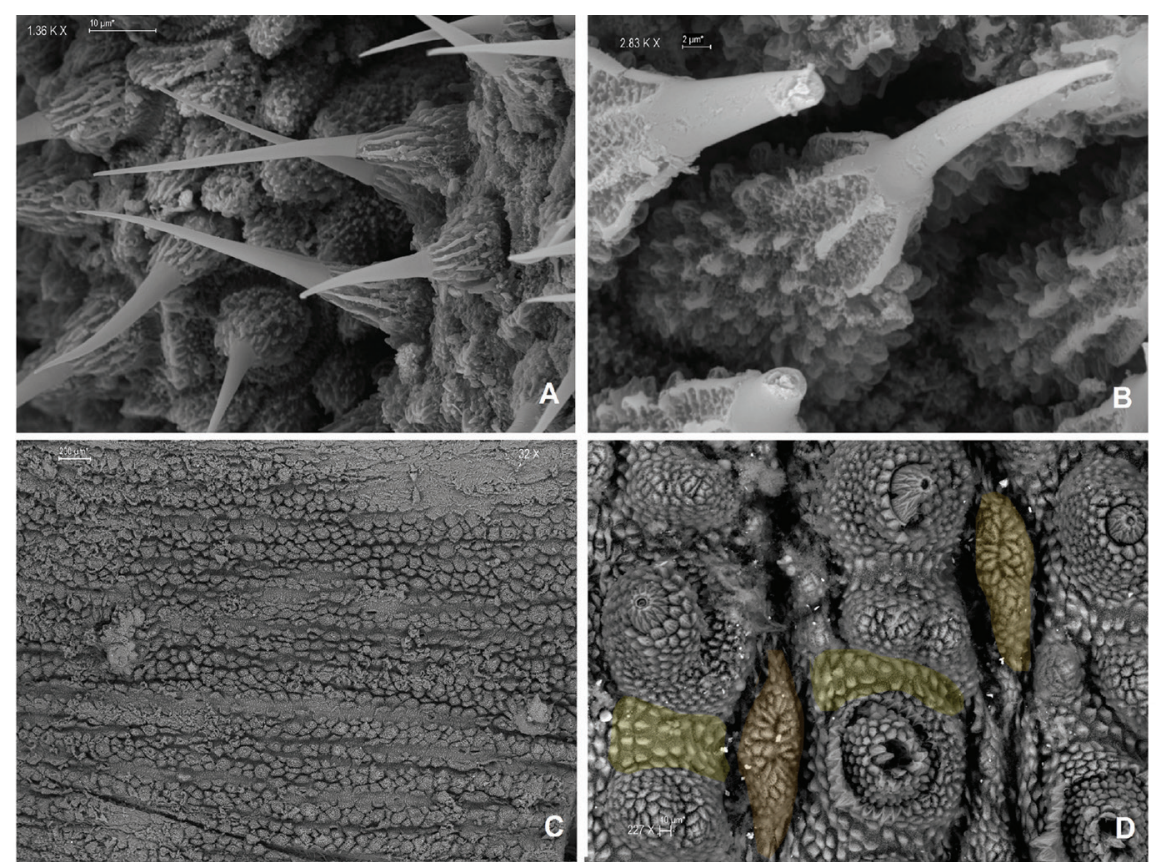

Fig. 7. A. Two types of bristles are found on spinous pads. One type presents long roots and a small base with few scale ranks; B. The second type has short roots and a base with various scale ranks; C. Ventral integument condition avoided proper examination; D. Type I crater shaped papillae (orange) with no apical piece and peculiar integument folds that separate papillae (yellow) are observed. (Color in digital version).
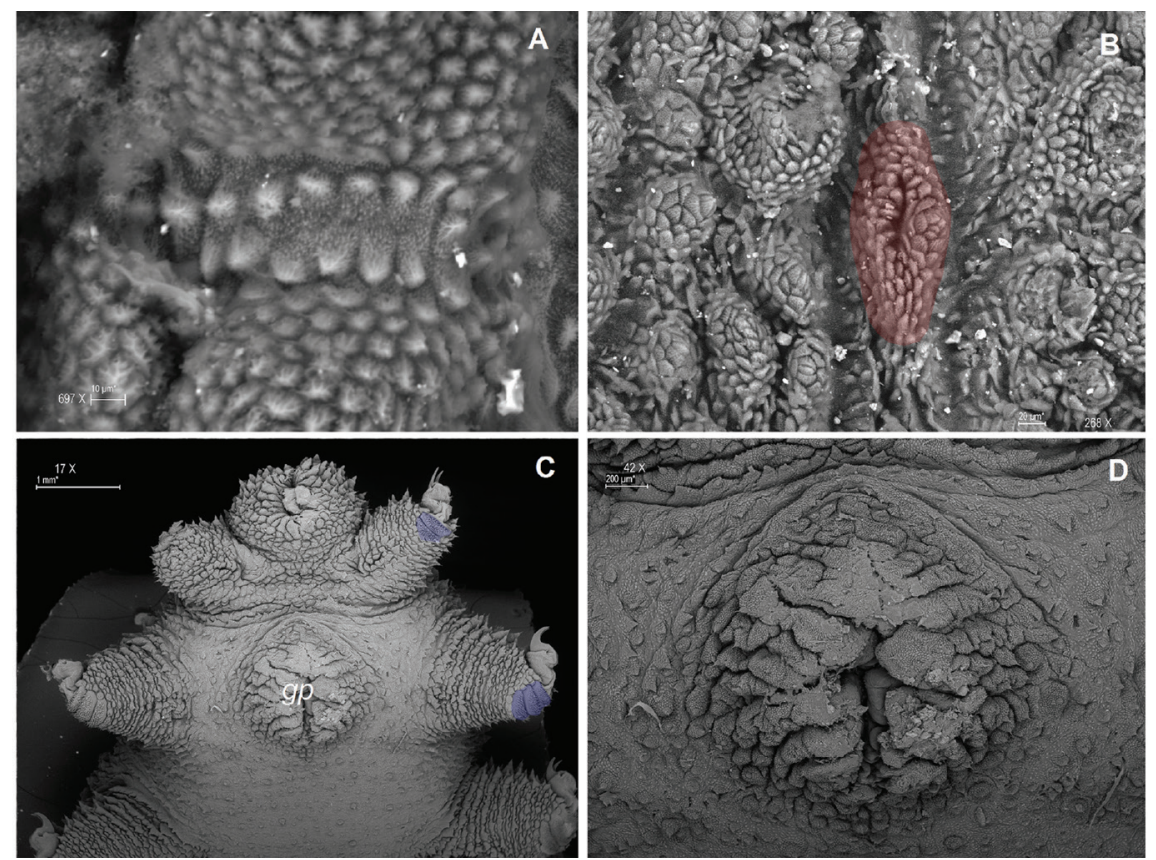

Fig. 8. A. Detailed view of the peculiar ventral integument folds that separate primary papillae; B. Type II crater shaped papillae with rudimentary apical piece (red); C. Ventral view of last pairs of legs with two spinous pads and gonopore; D. Detailed female gonopore. (Color in digital version). 

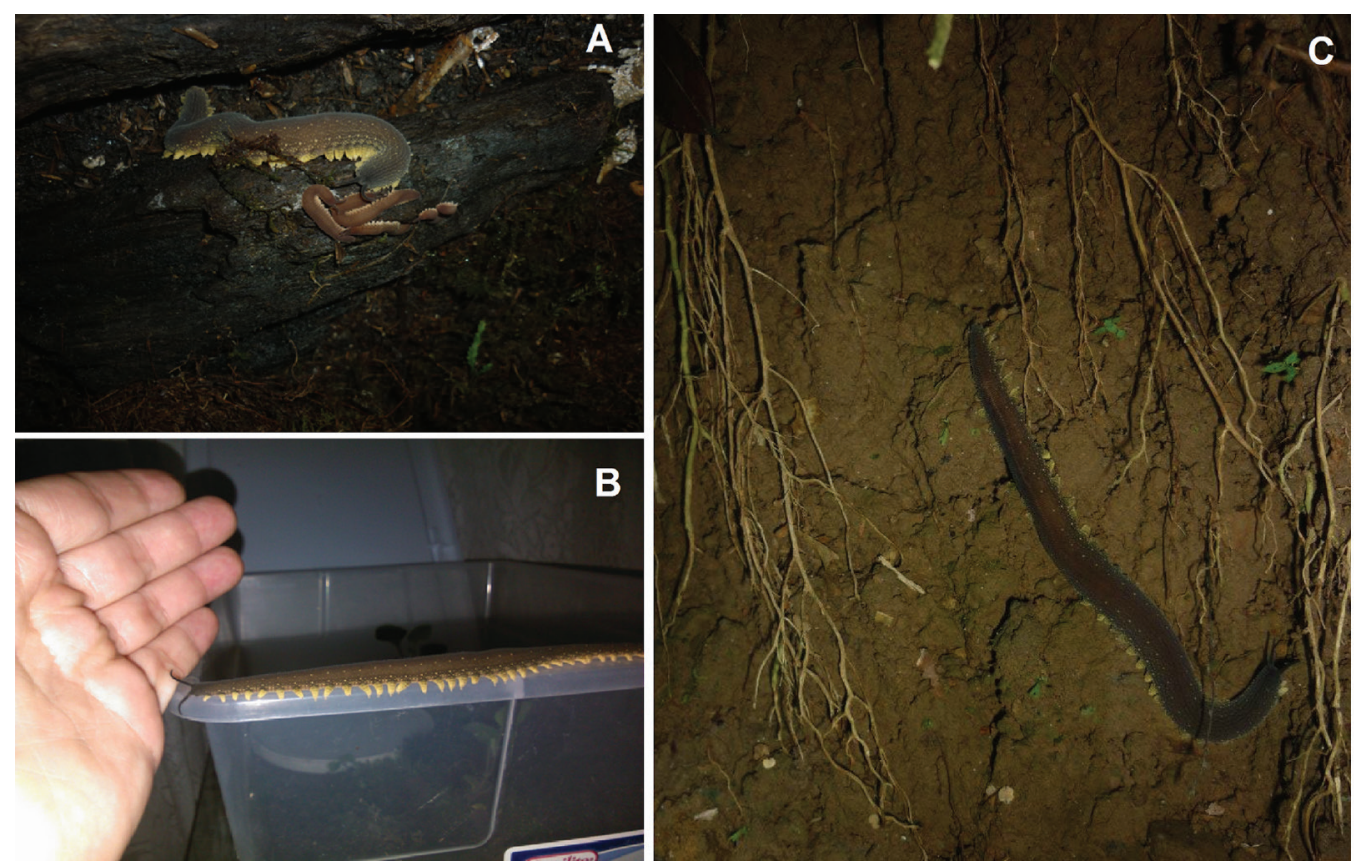

Fig. 9. A. Adult specimen with bluish grey coloration and two rows of yellow papillae, its offspring has a pinkish brown color; B. Our biggest female size almost resembles that of P. solorzanoi; C. Female in its natural habitat. (Color in digital version).

Posterior region. Female gonopore is a longitudinal slit (Fig. 8C, Fig. 8D). Male structures are unknown.

Color pattern. Bluish brown to grayish purple, two dorsal rows of yellow colored papillae at each side of the body, yellow legs and dark antennae (Fig. 9A). Neonates with a pinkish-brown coloration, white-yellow legs and dark antennae (Fig. 9B).

Behavior and habitat. Our specimen was collected in Keköldi Indigenous Reserve, at a soil wall next to a creek (Fig. 9C). Additional observations include one individual in a burrow at a forest (Javier Tenorio pers. comm.) and another under a rock near a creek (Michael Segura pers. comm). In captivity, our specimen gave birth to numerous offspring and stayed in close contact with them for about three days after birth, behaviors such as food sharing were recorded, young individuals fed on the glue strings used to capture prey rather than the prey itself (Barquero-González et al., 2019). Other specimens were photographed in Manzanillo, Limón in a banana plantation (Alejandra Barrantes pers. comm.).

Species etymology: The species is named in honor of its type locality: the Keköldi Indigenous Reserve. The Bribri indigenous group gave the reserve's name. It means "río bastón del awá" or "the river that supports the awá". Awá means doctor in the Bribri language.

\section{Species description}

\section{Mongeperipatus solorzanoi}

(Morera-Brenes \& Monge-Najera, 2010).

comb. nov.

Synonyms: Peripatus solorzanoi, by original designation (Morera-Brenes \& MongeNájera, 2010).

Holotype: Deposited in the Museo de Zoología of Universidad de Costa Rica, San José, Costa Rica (MZUCR-59-01). 
Type locality: COSTA RICA, Limón, Guayacán de Siquirres, $10^{\circ} 02^{\prime} 58^{\prime \prime} \mathrm{N}, 83^{\circ} 32^{\prime} 31^{\prime}$ ' $\mathrm{W}, 400-500 \mathrm{~m}$.

Diagnosis: Four spinous pads per leg; 5-12 accessory papillae between two primary ones; up to 18 scale ranks on primary papillae bases; a rudimentary tooth on inner jaws; males with 34 pairs of legs and females with 39-41 pairs.

Behavior and habitat: This species can be found both in forests and in semi-altered areas specifically near streams. It has been observed in burrows on the margins of these water bodies or frequenting the soil walls adjacent to them. It is rarely seen inside the forest. It has been reported that some of these animals can feed on crayfish in their natural habitat. When bothered, they usually expel large amounts of adhesive slime as a defense mechanism.

\section{DISCUSSION}

The new species Mongeperipatus keköldi gen. nov. et sp. nov lacks the autapomorphies of the described Peripatidae genera (Oliveira et al., 2012a, 2014). It differs from Eoperipatus (Evans, 1901), Heteroperipatus (Zilch, 1954) Oroperipatus and Typhloperipatus (Kemp, 1913) because it presents one posterior and two anterior distal foot papillae. Since the primary papillae shape is roundish, they are not Macroperipatus. Additionally, since it has four complete spinous pads rather than three, it is neither Mesoperipatus (Evans, 1901). On the other hand, its 12 dorsal plicae, instead of 24, are not compatible with Plicatoperipatus (Clark, 1913). Its pigmentation and functional eyes are inconsistent with Speleoperipatus (Clark, 1913). This species is also not associated with Cerradopatus (Oliveira et al., 2013) given the absence of a large genital pad, covered with modified scales in females.

Nevertheless, it shared some characters with Principapillatus (Oliveira et al., 2012a) like the dorsal integument pattern, alternating largest and medium-sized primary papillae, and the plica with large primary and accessory papillae followed by plica with small mid-sized primary and accessory papillae. However, the size, number of pairs of legs, and spinous pads number and shape are different from Mongeperipatus. The type Peripatus (P. juliformis Guilding, 1826), has a lower number of legs, poorly limited hyaline organs, and primary papillae apical piece larger than the basal piece (Read, 1988a, 1988b). Since this is not observed in the Costa Rican species, we concluded that it wasn't Peripatus.

It is important to point out that Macroperipatus and Epiperipatus are problematic genera (Oliveira \& Wieloch, 2005, Oliveira et al., 2010, 2012a): considering the general onychophoran biology, they exhibit an unlikely broad distribution (Oliveira et al., 2011; Daniels et al., 2016; Cunha et al., 2017; Giribet et al., 2018; Sato et al., 2018; Barnes \& Daniels, 2019), which causes an overlap in characters with those of other genera. This is especially true in Epiperipatus (Sampaio-Costa et al., 2018), as its diagnostic characters are present in most species. For example, all described species of Costa Rica fit within Epiperipatus: E. isthmicola, (Bouvier, 1902a); E. biolleyi, (Bouvier, 1902b); P. ruber, (Fuhrmann, 1913); Ma. valerioi, (Morera-Brenes \& Léon, 1986); E. hilkae, (Morera-Brenes \& Monge-Nájera, 1990); $P$. solorzanoi, (Morera-Brenes \& Monge-Nájera, 2010); Pr. hitoyensis, (Oliveira et al., 2012a) an issue not reflected in our molecular analysis. We suggest that true representatives of Epiperipatus are restricted to the Guyanan Shield as the phylogeny shows. Therefore, morphological studies should focus solely on them in order to elucidate diagnostic features.

In our phylogenetic analysis, non-amazonic Brazilian species formed one clade, becoming a sister group of Guyanan Shield samples (P. basilensis was included here). The Caribbean Islands samples did not constitute a group. In addition, the Central American clade contained the sample from Venezuela; E. vagans was the only Panamanian sample not included in it. Similar findings were reported on a previous study (Giribet et al., 2018). Mongeperipatus is within the latter group, composed by the 
species M. keköldi and P. solorzanoi. Based on what was previously stated, we suggest that the sample MCZ130840 from Hitoy Cerere may be a third species of this genus. Its weak support is caused by the comparison of only the $12 \mathrm{~S}$ gene. This monophyletic clade was related to $P r$. hitoyensis from the Caribbean of Costa Rica. As stated above, neither the Guyanan Shield nor the Caribbean Island samples (home of the genera Epiperipatus and Peripatus respectively) are closely related to Mongeperipatus. Thereby, we believe that true representatives from both genera are absent in Central America. Even though, the DNA of P. juliformis from Saint Vincent Island is unavailable (Giribet et al., 2018), the geographic clades found suggest that it should be grouped within the Caribbean Islands representatives rather than with the Costa Rican-Panamanian ones.

On the other hand, Giribet and collaborators (2018) showed a lack of genetic support in evolutionary relationships between the accepted genera within Neotropical Peripatidae. Nevertheless, their results confirmed the two main clades validated by Bouvier (1905): those that are distinguished by the number of foot papillae and position of the nephridial tubercle. This fact collates with the nearly complete lack of diagnostic characters at the generic level that bear phylogenetic significance (SampaioCosta, 2016). A strong suggestion by many to solve this conflict is going back to Bouvier's system and split the group in two broad genera: Oroperipatus (Andean clade) and Peripatus (Caribbean clade). They maintain that it is completely unnecessary to create more genera.

We do not agree with this drastic solution for many reasons. Firstly, a strict attachment to the Bouvier's system would force us to include the African Mesoperipatus within Peripatus, as it displays typical Caribbean clade morphology (nephridial tubercle on the fourth and fifth legs between the third and fourth spinous pads, and two prolateral and one retrolateral foot papillae). Hence, the proposal of Neopatida as a supra-generic taxon would be discarded, consequently neglecting the contribution of the modern phylogenetic analyses. Except for the pioneer works of Trewick (1998, 1999, 2000), none other onychophoran's taxonomist has recognized that molecular genetics is the best tool available to identify taxa within this phylum (see Gleeson \& Ruhberg, 2010). Particularly, for cryptic species, this is possibly the only way (Briscoe, \& Tait, 1995; Daniels et al., 2016; Cunha et al., 2017; Sato et al., 2018). Certainly, morphology and biogeography should be used as auxiliary tools.

Secondly, by accepting only two genera, the identification in the field may be greatly simplified, but it makes it impossible to understand the systematic relationships between the Neotropical species. Thirdly, it should be considered that, in recent phylogenetic analyses (Giribet et al., 2018; and this paper), the internal branches on the Caribbean clade are very short and have low support, which creates in fact polytomies. Our interpretation is that the four studied genes (1 nuclear and 3 mitochondrial) lack enough information to solve robustly such clades at the generic level. Indeed, exome or whole genome analyses may corroborate or reject this statement. Our recommendation - if it is necessary - is to propose new genera based on monophyletic geographic clades in which the relationships can be proven by genetics and morphology.

Given our results, we suggest assigning P. solorzanoi to Mongeperipatus, as genetics and morphology reflect this relationship. Both species are giants, even though body size is considered of little taxonomic use given the difficulties in measuring them (Read, 1988a). Representatives of this genus can exceed 18 $\mathrm{cm}$, making them unmistakable with other onychophorans (Dzik, \& Krumbiegel, 1989; Morera-Brenes, \& Monge-Nájera, 2010). The other integument features mentioned above, and the remarkable sexual dimorphism in the number of leg pairs, the highest reported for Central-American species (Monge-Nájera, 1994), which is only comparable to inhabitants of some South-American (von Kennel, 1883; Schmarda, 1871; Sampaio-Costa et al., 2018) and Caribbean Island species (Clark, 1913) are present in both. 
M. keköldi is differentiated from M. solorzanoi by their vestigial fifth spinous pad, the number of accessory papillae between the two primary ones, the number of scale ranks on the largest primary papillae; the number of pairs of legs in both sexes and by the rudimentary tooth in the inner jaw. Characters like head pattern, modified accessory papillae, "cephalic papillae" and lack of antennal chemoreceptors are only reported in M. keköldi, but a detailed redescription of M. solorzanoi (which is pending) may reveal they also have it. Morera-Brenes and Monge-Nájera (2010) erroneously considered M. solorzanoi as a real Peripatus because it fulfilled the criteria of: "four or more scale ranks in the apical piece" (Fig. 3), established by Read (1988b). However, once we conducted the new scanning electron micrographs of $M$. keköldi $\mathrm{n}$. sp. and the phylogenetic analysis as a reference, we realized the artificial location of this species within that genus. At same time, both big species seem to be closely related to each other and this suggests they belong to a previously un-described genus. Their mistake was caused by the fact that such trait alone (apical piece of primary papillae) is insufficient to differentiate between the Caribbean genera. At most, it is barely useful to separate between Peripatus and "Epiperipatus" on the Antillean arc. Therefore, more comprehensive and robust set of characters must be found to distinguish between the Neotropical Peripatidae genera.

A characteristic head pattern was also found in Pr. hitoyensis, but it had three large primary papillae forming a triangle (Oliveira et al., 2012a), rather than six primary papillae surrounding the lower part of an oval shaped space with less-developed accessory papillae of smooth appearance, that resembled some species of Peripatopsidae (Reid, 1996). While primary papillae number, base shape, and scales rows have served to distinguish various Neotropical Peripatids (Bouvier, 1899, 1905; Read, 1988a; Oliveira et al., 2010, 2012a), accessory papillae have not received enough attention. M. keköldi's peculiar accessory papillae showed the occurrence of an unexplored diversity within them in need of additional studies. This is the first report in Peripatidae of such characters states, particularly the round paired papillae lacking an apical piece located between the antennal bases - which we named cephalic papillae - increasing the diversity of known structures in the phylum.

The previous characteristics and the absence of visible chemoreceptors in the antennae exemplify the morphological complexity of Neotropical Peripatids, capable of giving better taxonomic distinctions at species level. While some authors have argued that teeth shape and number of denticles are variable within a species (Marcus \& Marcus, 1955; Oliveira et al., 2010), it is recommended conducting a detailed revision in several species to confirm such statement. Similar studies on unidentified species are urgent (Barquero-González et al., 2016b), particularly since SINAC's officers have recently reported illegal extraction of specimens from the reserve by scientists from first-world countries (Ronald Mora pers. comm). This is a concern because it is a direct threat to the species population and these individuals should face the corresponding legal consequences. Costa Rica harbors a diverse Onychophoran fauna that needs to be described and protected.

Ethical statement: authors declare that they all agree with this publication and made significant contributions; that there is no conflict of interest of any kind; and that we followed all pertinent ethical and legal procedures and requirements. All financial sources are fully and clearly stated in the acknowledgements section. A signed document has been filed in the journal archives.

\section{ACKNOWLEDGMENTS}

We thank Alejandra Barrantes, the first person to report the species to scientists, and Sthephanie Valle, Fabrizzio Protti, Cristian Castillo, Javier Tenorio and Jean Carlo McQueen for their assistance in the field work. Additionally, big thanks to Michael Segura and Javier Tenorio for their reports; Crista Montiel 
and Tahiris Calderón for their assistance in laboratory work. We extend our thanks to Sebastian Hernández for his guidance in the location and for giving us the permission to collect the specimen; SINAC's personnel for their attention and support. This study was financed by Project 0094-17 at the Universidad Nacional de Costa Rica.

\section{RESUMEN}

Un nuevo onicóforo gigante de Costa Rica sugiere la ausencia del género Peripatus (Onychophora: Peripatidae) en América Central. Introducción: Los onicóforos del neotrópico han sido poco estudiados, especialmente en cuanto a taxonomía y diversidad. Sin embargo, estudios recientes sugieren que los géneros actuales son obsoletos y el número de especies existentes es desconocido. Por ejemplo, en Costa Rica, se han reportado diversos onicóforos que no han sido identificados exitosamente. Objetivo: El objetivo de este trabajo fue evaluar la presencia de los géneros aceptados en el país, y describir un nuevo género y especie para Centroamérica. Métodos: En el 2017, recolectamos un espécimen de onicóforo en la reserva indígena de Keköldi en Talamanca, Limón, Costa Rica, el cual dio a luz a varias crías. Incluyendo a este animal, estudiamos un total de siete especímenes. Mediante el uso de microscopía de luz, observamos las características morfológicas macroscópicas en todas las muestras. Asimismo, utilizamos la microscopía electrónica para analizar detalladamente la morfología en una de estas. Finalmente, realizamos un análisis filogenético con la secuencia correspondiente de COI. Resultados: Un nuevo onicóforo gigante fue descrito. Se propuso un nuevo género, el cual se distingue por su tamaño gigante, el número de filas de escamas en la pieza apical de las papilas primarias, sus grandes papilas primarias cónicas, la línea media flanqueada por dos-tres papilas accesorias, la ausencia de órganos hialinos y el dimorfismo sexual marcado respecto al número de patas. Esta especie presenta un patrón particular de papilas en su cabeza, además de estructuras nuevas como papilas modificadas en la cabeza (papilas cefálicas), papilas accesorias con piezas apicales rudimentarias y la ausencia de quimiorreceptores en las antenas. Los análisis filogenéticos lo sitúan como un género monofilético que incluye a Peripatus solorzanoi, tal clado se encuentra dentro del grupo de especies centroamericanas. Por lo tanto, la nueva especie se agrupa dentro de las muestras pertenecientes a Costa Rica-Panamá. Este grupo no se relaciona con los especímenes de las islas caribeñas ni del Escudo Guyanés, hogares de las especies tipo de Epiperipatus y Peripatus respectivamente. De modo que sugerimos que estos géneros no están presentes en Centroamérica. Así entonces, describimos el nuevo género Mongeperipatus para Costa Rica. Conclusión: Este país alberga una diversidad de onicóforos sin describir, que se requieren estudios puntuales que ayuden a aclarar la taxonomía y relaciones evolutivas del grupo para justificar la protección del filo.

Palabras clave: especiación de onicóforos, biodiversidad de Costa Rica, endemismo, fauna saproxílica, filogenética.

\section{REFERENCES}

Akaike, H. (1973). Maximum likelihood identification of Gaussian autoregressive moving average models. Biometrika, 60(2), 255-265.

Allwood, J., Gleeson, D., Mayer, G., Daniels, S., Beggs, J.R., \& Buckley, T.R. (2010). Support for vicariant origins of the New Zealand Onychophora. Journal of Biogeography, 37(4), 669-681.

Baer, A., Hänsch, S., Mayer, G., Harrington, M.J., \& Schmidt, S. (2018). Reversible supramolecular assembly of velvet worm adhesive fibers via electrostatic interactions of charged phosphoproteins. Biomacromolecules, 19(10), 4034-4043.

Barquero-González, J.P., Acosta-Chaves, V.J., Sotela, M.L., Brenes, F.V., \& Morera-Brenes, B. (2016a). Evidencia fotográfica de especies desconocidas de onicóforos (Onychophora: Peripatidae) de Costa Rica. UNED Research Journal, 8(2), 139-147.

Barquero-González, J.P., Alvarado Cabrera, A., ValleCubero, S., Monge-Nájera, J., \& Morera-Brenes, B. (2016b). The geographic distribution of Costa Rican velvet worms (Onychophora: Peripatidae). Revista de Biología Tropical, 64(4), 1401-1414.

Barquero-González, J.P., Morera-Brenes, B., \& MongeNájera, J. (2018). The relationship between humidity, light and the activity pattern of a velvet worm, Epiperipatus sp. (Onychophora: Peripatidae), from Bahía Drake, South Pacific of Costa Rica. Brazilian Journal of Biology, 78(3), 408-413.

Barquero-González, J.P., Vega-Hidalgo, A., \& MongeNájera, J. (2019). Feeding behavior of Costa Rican velvet worms: food hiding, parental feeding investment and ontogenetic diet shift (Onychophora: Peripatidae). UNED Research Journal, 11(2), 85-88.

Barnes, A., \& Daniels, S.R. (2019). On the importance of fine-scale sampling in detecting alpha taxonomic diversity among saproxylic invertebrates: A velvet worm (Onychophora: Opisthopatus amaxhosa) template. Zoologica Scripta, 48(2), 243-262.

Bouvier, E.L. (1899). Contribution a l'histoire des Péripates Américanes. Annales de la Societé Entomologique de France, 68, 385-450.

Bouvier, E.L. (1902a). Un Péripate de Costa-Rica. Bulletin de la Société Entomologique de France, 7(15), 239-240. 
Bouvier, E.L. (1902b). Peripatus biolleyi, Onychophore nouveau de Costa Rica. Bulletin de la Société Entomologique de France, 16, 258-259.

Bouvier, E.L. (1905). Monographie des Onychophores I. Annales des Sciences Naturelles, 9(2), 1-383.

Braband, A., Podsiadlowski, L., Cameron, S.L., Daniels, S., \& Mayer, G. (2010a). Extensive duplication events account for multiple control regions and pseudo-genes in the mitochondrial genome of the velvet worm Metaperipatus inae (Onychophora, Peripatopsidae). Molecular Phylogenetics and Evolution, 57(1), 293-300.

Braband, A., Cameron, S.L., Podsiadlowski, L., Daniels, S.R., \& Mayer, G. (2010b). The mitochondrial genome of the onychophoran Opisthopatus cinctipes (Peripatopsidae) reflects the ancestral mitochondrial gene arrangement of Panarthropoda and Ecdysozoa. Molecular Phylogenetics and Evolution, 57(1), 285-292.

Brinck, P. (1957). Onychophora, a review of South African species, with a discussion on the significance of the geographical distribution of the group. South African Animal Life, 4, 7-32.

Brito, S.V., Pereira, J.C., Ferreira, F.S., Vasconcellos, A., \& Almeida, W.O. (2010). Epiperipatus cratensis sp. nov. (Onychophora: Peripatidae) from northeastern Brazil. Neotropical Biology and Conservation, 5(1), 47-52.

Briscoe, D.A., \& Tait, N.N. (1995). Allozyme evidence for extensive and ancient radiations in Australian Onychophora. Zoological Journal of the Linnean Society, 114(1), 91-102.

Castresana, J. (2000). Selection of conserved blocks from multiple alignments for their use in phylogenetic analysis. Molecular Biology and Evolution, 17(4), 540-552.

Carvalho, A. (1941). Nota prévia sôbre uma nova espécie de "Peripatus" do Brasil Central. Brazilian Journal of Biology, 1(4), 447-448.

Chagas-Júnior, A., \& Sampaio Costa, C. (2014). Macroperipatus ohausi: redescription and taxonomic notes on its status (Onychophora: Peripatidae). International Journal of Tropical Biology and Conservation, 62(3), 977-985.

Clark, A.H. (1913). A revision of the American species of Peripatus. Proceedings of the Biological Society of Washington, 26, 15-19.

Cockerell, T.D.A. (1908). Monographie des Onychophores by Bouvier. Science, 27, 619-621.

Concha, A., Mellado, P., Morera-Brenes, B., Costa, C., Mahadevan, L., \& Monge-Nájera, J. (2015). Oscillation of the velvet worm slime jet by passive hydrodynamic instability. Nature Communications, 6, 6292 .

Corrales-Ureña, Y.R., Sanchez, A., Pereira, R., Rischka, K., Kowalik, T., \& Vega-Baudrit, J. (2017). Extracellular micro and nanostructures forming the velvet worm solidified adhesive secretion. Materials Research Express, 4(12), 125013.

Cunha, W.T., Santos, R.C., Araripe, J., Sampaio, I., Schneider, H., \& Rêgo, P.S. (2017). Molecular analyses reveal the occurrence of three new sympatric lineages of velvet worms (Onychophora: Peripatidae) in the eastern Amazon basin. Genetics and Molecular Bio$\log y, 40(1), 147-152$.

Daniels, S.R. (2011). Genetic variation in the Critically Endangered velvet worm Opisthopatus roseus (Onychophora: Peripatopsidae). African Zoology, 46(2), 419-424.

Daniels, S.R., Picker, M.D., Cowlin, R.M., \& Hamer, M.L. (2009). Unravelling evolutionary lineages among South African velvet worms (Onychophora: Peripatopsis) provides evidence for widespread cryptic speciation. Biological Journal of the Linnean Society, 97(1), 200-216.

Daniels, S.R., \& Ruhberg, H. (2010). Molecular and morphological variation in a South African velvet worm Peripatopsis moseleyi (Onychophora, Peripatopsidae): evidence for cryptic speciation. Journal of Zoology, 282(3), 171-179.

Daniels, S.R., McDonald, D.E., \& Picker, M.D. (2013). Evolutionary insight into the Peripatopsis balfouri sensu lato species complex (Onychophora: Peripatopsidae) reveals novel lineages and zoogeographic patterning. Zoologica Scripta, 42(6), 656-674.

Daniels, S.R., Dambire, C., Klaus, S., \& Sharma, P.P. (2016). Unmasking alpha diversity, cladogenesis and biogeographical patterning in an ancient panarthropod lineage (Onychophora: Peripatopsidae: Opisthopatus cinctipes) with the description of five novel species. Cladistics, 32(5), 506-537.

Dzik, J., \& Krumbiegel, G. (1989). The oldest onychophoran, Xenusion - a link connecting phyla. Lethaia, 22, 169-181.

Evans, R. (1901). On two new species of Onychophora from the Siamese Malay States. Quarterly Journal of Microscopical Science, 44, 473-538.

Fuhrmann, O. (1913). Quelques nouveaux Péripates américains. Mémoires de la Société Neuchâteloise des Sciences Naturelles, 5, 176-192.

Garwood, R.J., Edgecombe, G.D., Charbonnier, S., Chabard, D., Sotty, D., \& Giribet, G. (2016). Carboniferous Onychophora from Montceau les Mines, France, and onychophoran terrestrialization. Invertebrate Biology, 135(3), 179-190. 
Giribet, G., Buckman-Young, R.S., Costa, C.S., Baker, C.M., Benavides, L.R., Branstetter, M.G., \& Pinto-da-Rocha, R. (2018). The 'Peripatos' in Eurogondwana?-Lack of evidence that south-east Asian onychophorans walked through Europe. Invertebrate Systematics, 32(4), 840-863.

Gleeson, D.M., \& Ruhberg, H. (2010). Phylum Onychophora-velvet worms, peripatus. New Zealand Inventory of Biodiversity: Kingdom Animalia, 2, 36-39.

Guilding, L. (1826). Mollusca Carribbeana. The Zoological Journal, 2, 437-449.

Haritos, V.S., Niranjane, A., Weisman, S., Trueman, H.E., Sriskantha, A., \& Sutherland, T.D. (2010). Harnessing disorder: onychophorans use highly unstructured proteins, not silks, for prey capture. Proceedings of the Royal Society of London B: Biological Sciences, 277(1698), 3255-3263.

Holdridge, L.R. (1967). Life zone ecology. San José, Costa Rica: Centro Científico Tropical.

Katoh, K., Kuma, K., Toh, H., \& Miyata, T. (2005). MAFFT version 5: improvement in accuracy of multiple sequence alignment. Nucleic Acids Research, $33,511-518$.

Kemp, S. (1913). Preliminary note on a new genus of Onychophora from the N. E. frontier of India. Records of the Indian Museum, 9, 241-242.

von Kennel, J. (1883). Entwicklungsgeschichte von Peripatus. Zoologischer. Anzeiger, 6(150), 531-537.

Kuraku, S., Zmasek, C.M., Nishimura, O., \& Katoh, K. (2013). aLeaves facilitates on-demand exploration of metazoan gene family trees on MAFFT sequence alignment server with enhanced interactivity. Nucleic Acids Research, 41, W22-W28.

Lacorte, G.A., Oliveira, I.S., \& Fonseca, C.G. (2011). Population structure and demographic inferences concerning the endangered onychophoran species Epiperipatus acacioi (Onychophora: Peripatidae). Genetics and Molecular Research, 10(4), 2775-2785.

Lavallard, R., \& Campiglia, S. (1975). Contribution a la biologie de Peripatus acacioi Marcus et Marcus (Onychophore). V. Etude des Naissances dans un elevage de laboratiore. Zoologischer Anzeiger, 195, 338-350.

Marcus, E., \& Marcus, E. (1955). A new Peripatus from Minas Gerais, Brazil. Anais da Academia Brasileira de Ciencias, 27, 189-193.

Mayer, G. (2007). Metaperipatus inae sp. nov. (Onychophora: Peripatopsidae) from Chile with a novel ovarian type and dermal insemination. Zootaxa, 1440(1), 21-37.
Miller, M.A., Pfeiffer, W., \& Schwartz, T. (2010). Creating the CIPRES Science Gateway for inference of large phylogenetic trees. Gateway Computing Environments Workshop, 1-8.

Monge-Nájera, J. (1994). Reproductive trends, habitat type and body characteristics in velvet worms (Onychophora). Revista de Biología Tropical, 42(3), 611-622.

Monge-Nájera, J. (1995). Phylogeny, biogeography and reproductive trends in the Onychophora. Zoological Journal of the Linnean Society, 114(1), 21-60.

Monge-Nájera, J. (1996). Jurassic-Pliocene biogeography: testing a model with velvet worm (Onychophora) vicariance. International Journal of Tropical Biology and Conservation, 44(1), 147-152.

Monge-Nájera, J. (2017). The power of short lectures to improve support for biodiversity conservation of unpopular organisms: an experiment with worms. UNED Research Journal, 9(1), 145-150.

Monge-Nájera, J. (2018). City Worms (Onychophora): why do fragile invertebrates from an ancient lineage live in heavily urbanized areas? UNED Research Journal, 10(1), 91-94.

Monge-Nájera, J., Barrientos, Z., \& Aguilar, F. (1993). Behavior of Epiperipatus biolleyi (Onychophora: Peripatidae) under laboratory conditions. Revista de Biología Tropical, 41(3A), 689-696.

Monge-Nájera, J. \& Morera-Brenes, B. (2015). Velvet Worms (Onychophora) in Folklore and Art: Geographic Pattern, Types of Cultural Reference and Public Perception. British Journal of Education, Society \& Behavioural Science, 10(3), 1-9.

Mora, M., Herrera, A., \& León, P. (1996). The genome of Epiperipatus biolleyi (Peripatidae), a Costa Rican onychophoran. Revista de Biología Tropical, 44(1), 153-157.

Morera-Brenes, B., \& León, M.D. (1986). Description of Macroperipatus valerioi n. sp. from Costa Rica, and comments on the genus Macroperipatus (Onychophora: Peripatidae). Revista de Biología Tropical, 34(2), 277-282.

Morera Brenes, B., Monge-Nájera, J., \& Sáenz, R. (1988). Parturition in Onychophorans: New Record and a Review. Brenesia, 29, 15-20.

Morera-Brenes, B., \& Monge-Nájera, J. (1990). Epiperipatus hilkae, n. sp. from Costa Rica (Onychophora: Peripatidae). Revista de Biología Tropical, 38(2B), 449-456.

Morera-Brenes, B., \& Monge-Nájera, J. (2010). A new giant species of placented worm and the mechanism by which onychophorans weave their nets (Onychophora: Peripatidae). Revista de Biología Tropical, 58(4), 1127-1142. 
Murienne, J., Daniels, S.R., Buckley, T.R., Mayer, G., \& Giribet, G. (2014). A living fossil tale of Pangaean biogeography. Proceedings of the Royal Society of London B: Biological Sciences, 281(1775), 20132648.

Myburgh, A.M., \& Daniels, S.R. (2015). Exploring the impact of habitat size on phylogeographic patterning in the Overberg velvet worm Peripatopsis overbergiensis (Onychophora: Peripatopsidae). Journal of Heredity, 106(3), 296-305.

Oliveira, I.D.S., \& Wieloch, A.H. (2005). Macroperipatus machadoi sp. n. (Onychophora: Peripatidae) da floresta atlântica de Minas Gerais, Brasil. Lundiana, 6(supplement), 61-66.

Oliveira, I.S, Wieloch, A.H., \& Mayer, G. (2010). Revised taxonomy and redescription of two species of the Peripatidae (Onychophora) from Brazil: a step towards consistent terminology of morphological characters. Zootaxa, 2493, 16-34.

Oliveira, I.S., Lacorte, G.A., Fonseca, C.G., Wieloch, A.H., \& Mayer, G. (2011). Cryptic speciation in Brazilian Epiperipatus (Onychophora: Peripatidae) reveals an underestimated diversity among the peripatid velvet worms. Plos One, 6(6), e19973.

Oliveira, I.S., Franke, F.A., Hering, L., Schaffer, S., Rowell, D.M., Weck-Heimann, A., ... Mayer, G. (2012a). Unexplored character diversity in Onychophora (velvet worms): a comparative study of three peripatid species. PloS One, 7(12), e51220.

Oliveira, I.S., Read, V.S.J., \& Mayer, G. (2012b). A world checklist of Onychophora (velvet worms), with notes on nomenclature and status of names. ZooKeys, 211, $1-70$.

Oliveira, I.S., Schaffer, S., Kvartalnov, P.V., Galoyan, E.A., Plako, I.V., Weck-Heimann, A., Geissler, P., Ruhberg, H., \& Mayer, G. (2013). A new species of Eoperipatus (Onychophora) from Vietnam reveals novel morphological characters for the South-East Asian Peripatidae. Zoologischer Anzeiger-A Journal of Comparative Zoology, 252(4), 495-510.

Oliveira, I.S., Lacorte, G.A., Weck-Heimann, A., Cordeiro, L.M., Wieloch, A.H., \& Mayer, G. (2014). A new and critically endangered species and genus of Onychophora (Peripatidae) from the Brazilian savannah-a vulnerable biodiversity hotspot. Systematics and Biodiversity, 13(3), 211-233.

Oliveira, I.S., Bai, M., Jahn, H., Gross, V., Martin, C., Hammel, J.U., ... Mayer, G. (2016). Earliest onychophoran in amber reveals Gondwanan migration patterns. Current Biology, 26(19), 2594-2601.

Oliveira, I.S., Ruhberg, H., Rowell, D.M., \& Mayer, G. (2018). Revision of Tasmanian viviparous velvet worms (Onychophora: Peripatopsidae) with descriptions of two new species. Invertebrate Systematics, 32(4), 909-932.

Peck, S.B. (1975). A Review of the New World Onychophora with the Description of a New Cavernicolous Genus and Species from Jamaica. Psyche: A Journal of Entomology, 82(3-4), 341-358.

Picado, C. (1911). Sur un habitat nouveau des Peripatus. Bulletin du Musée National d'Histoire Naturelle, Paris, 17, 415-416.

Podsiadlowski, L., Braband, A., \& Mayer, G. (2008). The complete mitochondrial genome of the onychophoran Epiperipatus biolleyi reveals a unique transfer RNA set and provides further support for the Ecdysozoa hypothesis. Molecular Biology and Evolution, 25(1), 42-51.

Posada, D. (2008). jModelTest: phylogenetic model averaging. Molecular Biology and Evolution, 25(7), 1253-1256.

Rambaut, A., Drummond, A.J., Xie, D., Baele, G., \& Suchard, M.A. (2018). Posterior summarization in Bayesian phylogenetics using Tracer 1.7. Systematic Biology, 67(5), 901-904.

Read, V.S.J. (1985). The ecology of Macroperipatus torquatus (Kennel) with special reference to feeding and a taxonomic review (Doctoral dissertation). University of Wales, United Kingdom.

Read, V.S.J. (1988a). The application of scanning electron microscopy to the systematics of the neotropical Peripatidae (Onychophora). Zoological Journal of the Linnean Society, 93(3), 187-223.

Read, V.S.J. (1988b). The Onychophora of Trinidad, Tobago and the Lesser Antilles. Zoological Journal of the Linnean Society, 93(3), 225-257.

Reinhard, J., \& Rowell, D.M. (2005). Social behaviour in an Australian velvet worm, Euperipatoides rowelli (Onychophora: Peripatopsidae). Journal of Zoology, 267(1), 1-7.

Reid, A.L. (1996). Review of the Peripatopsidae (Onychophora) in Australia, with comments on peripatopsid relationships. Invertebrate Systematics, 10(4), 663-936.

Ronquist, F., Teslenko, M., van der Mark, P., Ayres, D.L., Darling, A., Höhna, S., ... Huelsenbeck, J.P. (2012). MrBayes 3.2: efficient Bayesian phylogenetic inference and model choice across a large model space. Systematic Biology, 61(3), 539-542.

Rota-Stabelli, O., Kayal, E., Gleeson, D., Daub, J., Boore, J.L., Telford, M.J., Pisani, D., Blaxter, M., \& Lavrov, D.V. (2010). Ecdysozoan mitogenomics: evidence for a common origin of the legged invertebrates, the Panarthropoda. Genome Biology and Evolution, 2, 425-440. 
Ruhberg, H. (1985). Die Peripatopsidae (Onychophora), Systematik, Ökologie, Chorologie und phylogenetische Aspekte. Zoologica, 137, 1-184.

Ruhberg, H., \& Hamer, M.L. (2005). A new species of Opisthopatus Purcell, 1899 (Onychophora: Peripatopsidae) from KwaZulu-Natal, South Africa. Zoota$x a, 1039(1), 27-38$.

Ruhberg, H., \& Daniels, S.R. (2013). Morphological assessment supports the recognition of four novel species in the widely distributed velvet worm Peripatopsis moseleyi sensu lato (Onychophora: Peripatopsidae). Invertebrate Systematics, 27(2), 131-145.

Sampaio-Costa, C., Chagas-Junior, A., \& Baptista, R.L. (2009). Brazilian species of Onychophora with notes on their taxonomy and distribution. Zoologia, 26(3), 553-561.

Sampaio-Costa, C. (2016). Sistemática e análise filogenética de Epiperipatus Clark, 1913 baseada em dados moleculares e morfológicos (Onychophora: Peripatidae) (Doctoral dissertation). Universidade de São Paulo, Brasil.

Sampaio-Costa, C., Chagas-Junior, A., \& Pinto-da-Rocha, R. (2018). Redescription of Epiperipatus edwardsii, and descriptions of five new species of Epiperipatus from Brazil (Onychophora: Peripatidae). Zoologia, $35,1-15$.

Sato, S., Buckman-Young, R.S., Harvey, M.S., \& Giribet, G. (2018). Cryptic speciation in a biodiversity hotspot: multilocus molecular data reveal new velvet worm species from Western Australia (Onychophora:
Peripatopsidae: Kumbadjena). Invertebrate Systematics, 32(6), 1249-1264.

Schmarda, L.K. (1871). I. Ordnung. Malacopoda Blainvi1le. Onychophora. Grube. Zoologie, 1(2), 74-76.

Sedgwick, A. (1888). A monograph on the species and distribution of the genus Peripatus (Guilding). Quarterly Journal of Microscopical Science, 28, 431-493.

Trewick, S. (1998). Sympatric cryptic species in New Zealand Onychophora. Biological Journal of the Linnean Society, 63(3), 307-329.

Trewick, S.A. (1999). Molecular diversity of Dunedin Peripatus (Onychophora: Peripatopsidae). New Zealand Journal of Zoology, 26(4), 381-393.

Trewick, S.A. (2000). Mitochondrial DNA sequences support allozyme evidence for cryptic radiation of New Zealand Peripatoides (Onychophora). Molecular Ecology, 9(3), 269-281.

Vaidya, G., Lohman, D.J., \& Meier, R. (2011). SequenceMatrix: concatenation software for the fast assembly of multigene datasets with character set and codon information. Cladistics, 27(2), 171-180.

Zilch, A. (1954). Onychophoren aus El Salvador. Senckenbergiana Biologica, 35, 147-150.

Zitani, N.M., Thorn, R.G., Hoyle, M., Schulz, J.M., Steipe, T., Ruiz, Y.B., Sarquis-Adamson, Y., \& Wishart, A.E. (2018). An Onychophoran and Its Putative Lepidopteran Mimic in the Arboreal Bryosphere of an Ecuadorian Cloud Forest. American Entomologist, 64(2), 94-101. 